\title{
Multistep Optimization of $\beta$-Glucosidase Extraction from Germinated Soybeans (Glycine max L. Merril) and Recovery of Isoflavone Aglycones
}

\author{
Luciane Yuri Yoshiara ${ }^{1}$, Tiago Bervelieri Madeira ${ }^{2}$, Adriano Costa de Camargo ${ }^{1,3, *}$ (D), \\ Fereidoon Shahidi ${ }^{3}$ (D) and Elza Iouko Ida ${ }^{1}$ \\ 1 Food Science Department, Londrina State University, Rod. Celso Garcia, KM 380, \\ 86051-990 Londrina, PR, Brazil; lyoshiara@hotmail.com (L.Y.Y.); elida@uel.br (E.I.I.) \\ 2 Chemistry Department, Londrina State University, Rod. Celso Garcia, KM 380, \\ 86051-990 Londrina, PR, Brazil; madeiratb@gmail.com \\ 3 Department of Biochemistry, Memorial University of Newfoundland, St. John's, NL A1B 3X9, Canada; \\ fshahidi@mun.ca \\ * Correspondence: adrianoesalq@gmail.com; Tel.: +55-19-99876-1128
}

Received: 21 June 2018; Accepted: 12 July 2018; Published: 13 July 2018

\begin{abstract}
Epicotyls from germinated soybeans (EGS) have great potential as sources of endogenous $\beta$-glucosidase. Furthermore, this enzyme may improve the conversion of isoflavones into their corresponding aglycones. $\beta$-Glucosidase may also increase the release of aglycones from the cell wall of the plant materials. Therefore, the aim of this work was to optimize both the extraction of $\beta$-glucosidase from EGS and to further examine its application in defatted soybean cotyledon to improve the recovery of aglycones, which were evaluated by ultra-high performance liquid chromatography (UHPLC). A multistep optimization was carried out and the effects of temperature and $\mathrm{pH}$ were investigated by applying a central composite design. The linear effect of $\mathrm{pH}$ and the quadratic effect of $\mathrm{pH}$ and temperature were significant for the extraction of $\beta$-glucosidase and recovery aglycones, respectively. Optimum extraction of $\beta$-glucosidase from EGS occurred at $30^{\circ} \mathrm{C}$ and $\mathrm{pH}$ 5.0. Furthermore, the maximum recovery of aglycones $(98.7 \%)$, which occurred at $35^{\circ} \mathrm{C}$ and $\mathrm{pH}$ 7.0-7.6 during $144 \mathrm{~h}$ of germination, increased 8.5 times with respect to the lowest concentration. The higher bioaccessibility of aglycones when compared with their conjugated counterparts is well substantiated. Therefore, the data provided in this contribution may be useful for enhancing the benefits of soybean, their products, and/or their processing by-products.
\end{abstract}

Keywords: endogenous enzyme; phenolic compounds; ultra-high performance liquid chromatography; response surface methodology

\section{Introduction}

Isoflavones are recognized in human health due to several biological properties, whereas in plants these bioactive compounds also have antifungal properties, thus protecting the plants against plant pathogens [1]. Epidemiological studies have shown that isoflavones may help reduce the risk of some chronic diseases [2]. In humans, a higher incidence of some types of cancers (e.g., breast and colon cancer) and heart disease has been observed in Western populations that consume lower amounts of soy isoflavones compared with the Asian population [3]. According to Brandi [4], isoflavones may reduce bone loss, decrease the risk of development of osteoporosis, and attenuate the symptoms of menopause in women. Because of their structural and molecular weight similarity to the group of female hormones secreted by ovarian cells (estrogens), isoflavones are also known as phytoestrogens [5]. 
Soybean isoflavones can be found in 12 different forms: $\beta$-glycosidics, which have a glucose unit linked to the benzene ring (e.g., daidzin, genistin, and glycitin); $\beta$-glycosidic conjugated forms, acetylglycosidics (e.g., acetyldaidzin, acetylgenistin, and acetylglycitin), and malonylglycosidics (e.g., malonyldaidzin, malonylgenistin, and malonylglycitin); and the aglycone forms (e.g., daidzein, genistein, and glycitein), which are not linked to glucose [6]. However, the contribution of the conjugated forms in soybeans are higher compared with that of the aglycone counterparts [7]. Furthermore, soybeans are regarded as the only high-level edible source of isoflavones. The distribution and content of different isoflavones are influenced by multiple factors, such as genetic variety, growth location, and crop year [8]. Likewise, isoflavone contents may vary among different soybean seed components. In fact, only minor amounts of isoflavones are present in the seed coat whereas the hypocotyls contain high concentrations and the cotyledons have been reported to contain $80-90 \%$ of the total isoflavones in the seed [9]. However, despite all these variations, the potential health benefits of soybeans as sources of isoflavones are well substantiated.

Walsh et al. [10] conducted an in vitro experiment to screen the stability and bioaccessibility of isoflavones from soy bread. According to these authors, micellarization may be required for optimal bioaccessibility of isoflavones in the aglycone forms. Furthermore, they suggested that the bioavailability of isoflavones from foods containing fat and protein may exceed that from supplements due to enhanced bile secretion. Therefore, due to the high protein content in soybeans, soybean products may be better sources of bioaccessible isoflavones. Isoflavones in the aglycone form are absorbed faster than their conjugated counterparts; therefore, they may render higher biological activities than the latter ones [11,12].

$\beta$-glucosidase catalyzes the hydrolysis of conjugated isoflavones, thus generating their respective aglycones. During the hydration of soybeans, this enzyme hydrolyzes glycosidic isoflavones, which affords their respective aglycones [13]. $\beta$-Glucosidase ( $\beta$-D-glucoside glucohydrolase, EC 3.2.1.21), which is commonly found in plants or as part of the metabolism of fungi and bacteria [14], catalyzes the hydrolysis of $\beta$-glycosidic di- and/or other glycoside conjugates and oligosaccharides from phenolic compounds, thus releasing both the sugar moiety and the aglycone. Because of this property, a high interest in applying $\beta$-glucosidase to increase the amount of aglycone isoflavones in soybean and soy products has been noted $[15,16]$. In intact plant tissues, $\beta$-glucosidases are stored in compartments separated from the substrate, thus playing an important role in the physiology of the plant. During germination, these enzymes act during the process of degradation and lignification of the cell walls of the plant material. Furthermore, they also act as plant growth regulators and during the activation of compounds related to the plant defense $[17,18]$.

The activation of enzymes (e.g., $\beta$-glucosidase) occurs during germination [19]. Therefore, germinated soybean components may be a good source of endogenous $\beta$-glucosidase which can be extracted and further applied in soy products, thus improving the final products due to higher contents of highly bioaccessible phenolic bioactives [20]. In epicotyls from germinated soybeans (EGS), the specific activity of the crude $\beta$-glucosidase extract has been reported to be 72 -fold higher than that of the cotyledon extract from ungerminated soybeans and 5.8-fold higher than that of the crude cotyledon extract from germinated soybeans under the same conditions. Therefore, epicotyls have been recommended as a potential industrial source of endogenous $\beta$-glucosidase for hydrolysis of conjugated isoflavones to obtain aglycones [21].

The extraction of endogenous $\beta$-glucosidases and the use of this enzyme for isoflavone conversion have not yet been well explored in comparison to those of enzymes of microbial origin. Furthermore, the central composite design (CCD) method is an important experimental design used in response surface methodology to construct a second-order model for the response variable without needing a complete three-level factorial experiment, thus reducing the number of experiments while providing trustworthy results. Response surface methodology (RSM) has been successfully used for developing, improving, and optimizing different processes, including the procurement and/or extraction of phenolic compounds [22-24]. Therefore, due to the importance of $\beta$-glucosidase, and the existing 
knowledge gap in the literature, the objective of this work was to use CCD to optimize both the extraction of $\beta$-glucosidase from EGS and to establish the best conditions to convert glycosidic isoflavones into their corresponding aglycones by treatment with extracts containing $\beta$-glucosidase.

\section{Materials and Methods}

\subsection{Materials}

Soybeans (cv. BRS 257) were developed by Embrapa Soybean (Londrina, PR, Brazil). Aglycones (daidzein, glicitein, and genistein) and acetylglucosides standards (daidzin, glycitin, genistin) were purchased from Sigma-Aldrich (Saint Louis, MO, USA). The remaining solvents and chemicals were of analytical or HPLC grade.

\subsection{Soybean Germination Process}

A previous study was used to select the germination conditions [21]. In this process, 15 germination paper rolls with 50 seeds each were placed in a germination chamber (Marconi, MA 835, Brazil). The seeds were then subjected to a photoperiod of $10 \mathrm{~h}$ of light per day. The temperature was kept at $35^{\circ} \mathrm{C}\left( \pm 1{ }^{\circ} \mathrm{C}\right)$ and controlled relative humidity $(100 \%)$ for $144 \mathrm{~h}$ [21]. The epicotyls were manually separated, freeze-dried (Christ, ALPHA 1-4 LD plus, Germany), ground (A11 Basic Mill, Ika, Brazil), and stored at $-26^{\circ} \mathrm{C}$ until analysis.

\subsection{CCD-Based Optimization of Extraction of Active $\beta$-Glucosidase}

The effect of temperature $\left(X_{1}=23,25,30,35\right.$, and $\left.37^{\circ} \mathrm{C}\right)$ and $\mathrm{pH}\left(X_{2}=3.6,4.0,5.0,6.0\right.$, and 6.4) on the extraction of active $\beta$-glucosidase from EGS was evaluated by applying the CCD with 5 levels of variation in a total of 11 assays (Table 1). Therefore, the response function $(Y)$ stems from the $\beta$-glucosidase activity. The extraction procedure was performed as described by Carrão-Panizzi and Bordingnon [25] using $0.1 \mathrm{~mol} \mathrm{~L}^{-1}$ sodium citrate buffer with $0.1 \mathrm{~mol} \mathrm{~L}^{-1} \mathrm{NaCl}$ at various $\mathrm{pH}$ values $\left(X_{1}\right)$ and temperatures $\left(X_{2}\right)$, according to the experimental design. The extraction procedure $(100 \mathrm{mg}$ of EGS in $1.5 \mathrm{~mL}$ sodium citrate buffer) was conducted under agitation for $50 \mathrm{~min}$. After centrifugation at $2500 \times g$ (Cientec, CT 600, Piracicaba, Brazil) for $15 \mathrm{~min}$, the extract so obtained was used for determination of $\beta$-glucosidase activity.

Table 1. Independent variables and variation levels for the central composite design for optimization of the extraction of active $\beta$-glucosidase from epicotyls from geminated soybeans.

\begin{tabular}{cccccc}
\hline \multirow{2}{*}{ Independent Variables } & \multicolumn{5}{c}{ Variation Levels } \\
\cline { 2 - 6 } & $\mathbf{- 1 . 4 1}$ & $\mathbf{- 1}$ & $\mathbf{0}$ & $\mathbf{+ 1}$ & $\mathbf{+ 1 . 4 1}$ \\
\hline$X_{1}=$ Temperature $\left({ }^{\circ} \mathrm{C}\right)$ & 23 & 25 & 30 & 35 & 37 \\
$X_{2}=\mathrm{pH}$ & 3.6 & 4.0 & 5.0 & 6.0 & 6.4 \\
\hline
\end{tabular}

2.4. CCD-Based Optimization of $\beta$-Glucosidase-Assisted Conversion of Conjugated Isoflavones into Their Corresponding Aglycones

Extracts with the highest $\beta$-glucosidase activity were used in this step of the experiment. A CCD with 2 variables $\left(X_{3}=\right.$ temperature and $X_{4}=\mathrm{pH}$ ) and 5 variation levels (Table 2 ) in 2 blocks was used. The first block consisted of a $2^{2}$ factorial design, a total of 7 assays (assays 1-7), and 2 variables with 3 variation levels $\left(X_{3}=20,35\right.$, and $50^{\circ} \mathrm{C}$ and $X_{4}=\mathrm{pH} 4.0,5.5$, and 7.0). The second block, with a total of 6 assays (assays 8-13) containing the axial points of the $\operatorname{CCD}\left(X_{3}=13.9\right.$ and $56.2^{\circ} \mathrm{C}$ and $X_{4}=\mathrm{pH}$ 3.39 , and 7.61), was performed to verify the quadratic effects. Previous experiments were conducted (data not shown) and the maximum conversion was achieved at $14 \mathrm{~h}$ of hydrolysis. The assays were performed randomly with defatted soybean cotyledon flours in $3.0 \mathrm{~mL}$ buffer $(1: 10 \mathrm{w} / \mathrm{v})$. According to each design, the $\mathrm{pH}$ values were adjusted with $0.1 \mathrm{M}$ sodium phosphate and $0.1 \mathrm{M}$ citric acid solutions. 
To each test tube, 5.0 units of $\beta$-glucosidase activity from EGS were added and shaken for $14 \mathrm{~h}$ at temperatures described in Table 2. The samples were freeze-dried and used for identification and quantification of isoflavones by ultra-high performance liquid chromatography (UHPLC). The response function stems from the percentage of aglycones ( $W=\%$ aglycones) obtained in relation to the total isoflavone content present in each sample.

Table 2. Independent variables and variation levels for the central composite design for optimization of the conversion of conjugated isoflavones into their corresponding aglycones.

\begin{tabular}{cccccc}
\hline \multirow{2}{*}{ Independent Variables } & \multicolumn{5}{c}{ Variation Levels } \\
\cline { 2 - 6 } & $\mathbf{- 1 . 4 1}$ & $\mathbf{- 1}$ & $\mathbf{0}$ & $\mathbf{+ 1}$ & $\mathbf{+ 1 . 4 1}$ \\
\hline$X_{3}=$ Temperature $\left({ }^{\circ} \mathrm{C}\right)$ & 13.9 & 20.0 & 35.0 & 50.0 & 56.2 \\
$X_{4}=\mathrm{pH}$ & 3.39 & 4.00 & 5.50 & 7.00 & 7.61 \\
\hline
\end{tabular}

\subsection{Determination of $\beta$-Glucosidase Activity}

The enzymatic activity was determined according to the method described in the literature [26] with slight modifications. Briefly, $0.4 \mathrm{~mL}$ of $16 \mathrm{mM}$-nitrophenyl-beta-D-glucopyranoside and $0.1 \mathrm{M}$ phosphate-citrate buffer ( $\mathrm{pH} 5.0)$ were transferred to a test tube and placed in a water bath at $30^{\circ} \mathrm{C}$ for $10 \mathrm{~min}$. The sample $(0.1 \mathrm{~mL})$ was added and the test tubes were placed in a water bath at $30{ }^{\circ} \mathrm{C}$ for $30 \mathrm{~min}$ more. The reaction was terminated with the addition of $0.5 \mathrm{M}$ sodium carbonate $(0.5 \mathrm{~mL})$. The concentration of $p$-nitrophenol released during the reaction was determined by reading the absorbance at $420 \mathrm{~nm}$ with a spectrophotometer (Biochrom Libra S22, Cambridge, England). For quantification, a $p$-nitrophenol $(20-160 \mathrm{mM})$ calibration curve was prepared. One unit of enzyme activity (UA) was defined as the amount of $\beta$-glucosidase that releases $1 \mathrm{mM} p$-nitrophenol $\mathrm{min}^{-1}$. The results were expressed as units of $\beta$-glucosidase activity $\left(\mathrm{UA} \mathrm{mL}^{-1}\right)$ per milliliter of extract.

\subsection{Extraction and Determination of Isoflavones by Ultra-High-Performance Liquid Chromatography (UHPLC)}

Defatted cotyledon soy flours subjected to enzymatic conversion were used for extraction. Water/ethanol/acetone (1:1:1 $v / v / v)$ was used for the extraction of isoflavones. The samples $(250 \mathrm{mg})$ were mixed with $6 \mathrm{~mL}$ of solvent and the extraction was performed under sonication at $60^{\circ} \mathrm{C}$ for $10 \mathrm{~min}$ [27]. After centrifugation and filtration (Millex-LH filters; $0.20 \mu \mathrm{m}$ ) of the supernatant, the extracts $(1.4 \mu \mathrm{L})$ were injected into the UHPLC (Acquity UPLC®System), with automatic system injection, oven with controlled temperature at $35^{\circ} \mathrm{C}$, and a diode array detector (Waters, Milford, MA, USA). A reversed-phase column, BEH C18 (Waters, $2.1 \mathrm{~mm} \times 50 \mathrm{~mm}, 1.7 \mu \mathrm{m}$ particles), was used. The binary mobile phase consisted of acidified water (glacial acetic acid, $\mathrm{pH}$ 3.0)-mobile phase A-and acetonitrile-mobile phase B. The elution gradient used was as follows: $0 \mathrm{~min}, 90 \% \mathrm{~A}$ and $10 \% \mathrm{~B} ; 8 \mathrm{~min}, 0 \% \mathrm{~A}$ and $100 \% \mathrm{~B}$. The initial condition was re-established at $9 \mathrm{~min}$. The total run took $12 \mathrm{~min}$ and the flow rate was $0.70 \mathrm{~mL} \mathrm{~min}{ }^{-1}$. The temperature was kept constant $\left(35^{\circ} \mathrm{C}\right)$ and a diode array detector (Waters) with a wavelength set at $260 \mathrm{~nm}$ was used. Isoflavones, namely daidzin, glycitin, genistin, daidzein, glicitein, and genistein, were identified and quantified by comparing their retention times and UV spectra with coded and authentic standards under the same conditions as the samples. The presence of acetyldaidzin, acetylgenistin, and acetylglycitin was also investigated with coded and authentic standards. However, they were not detected in any of the samples tested and/or treatments; this is common for raw soybeans [6]. According to the literature [28], malonylglucosides (malonyldaidzin, malonylglycitin, and malonylgenistin) were quantified based on the standard curves of the corresponding $\beta$-glycosidic isoflavones (daidzin, glycitin, and genistin, respectively) using the similarity of the extinction coefficients. Limits of detection and quantification for listed compounds ranged from 0.003 to 0.0239 and from 0.009 to $0.725 \mu \mathrm{g} / \mathrm{mL}$, respectively. Regression coefficients of the plotted graphs had $R^{2}$ ranging from 0.9988 to 0.9996 . 


\subsection{Statistical Analysis}

STATISTICA 8.0 software (StatSoft, Palo Alto, CA, USA) was used to determine the effects of independent variables, calculate the regression coefficient $\left(R^{2}\right)$, perform analysis of variance (ANOVA), and build the response surfaces at $5 \%$ significance. Data were adjusted to a second-order polynomial model (Equation (1)):

$$
y=\beta_{0}+\beta_{1} x_{1}+\beta_{2} x_{2}+\beta_{11} x_{1}^{2}+\beta_{22} x_{2}^{2}+\beta_{12} x_{1} x_{2}
$$

where $y$ is the response variable; $x_{1}$ and $x_{2}$ are the coded process variables; and $\beta_{0}, \beta_{1}, \beta_{2}, \beta_{11}, \beta_{22}$, and $\beta_{12}$ are the regression coefficients.

To evaluate and validate the mathematical models, a new assay was performed under the conditions $\left(X_{1}={ }^{\circ} \mathrm{C}\right.$ and $\left.X_{2}=\mathrm{pH}\right)$ that yielded the extracts with higher activity of $\beta$-glucosidase from EGS and the highest conversion of conjugated isoflavones into their respective aglycones $\left(X_{3}={ }^{\circ} \mathrm{C}\right.$ and $\left.\mathrm{X}_{4}=\mathrm{pH}\right)$. The observed model was obtained under experimental conditions, and the calculated values ( $\hat{y}$ and $\hat{w}$ ) were determined using the proposed model. The model was validated and the observed responses were within the confidence interval of the model.

\section{Results and Discussion}

\subsection{Optimization of $\beta$-Glucosidase Extraction from Germinated Soybean Epicotyls}

The linear effect of the variable $X_{1}$ (temperature) on the response function $y$ ( $\beta$-glucosidase activity) was not significant, whereas the linear effect of the variable $X_{2}(\mathrm{pH})$ was significant. In contrast, the quadratic effects of the variables $X_{1}$ and $X_{2}$ were significant but the interaction between the variables $X_{1}$ and $X_{2}$ was not significant (Table 3). These results indicated that variable $X_{2}$ (pH between 3.6 and 6.4) was essential to obtaining extracts with high $\beta$-glucosidase activity from epicotyls from germinated soybeans.

Table 3. Analysis of variance (ANOVA) for the $\beta$-glucosidase activity of extracts obtained from epicotyls from germinated soybeans.

\begin{tabular}{ccccccc}
\hline Variation Source & SS & DF & MS & F Test & $p$ & $\boldsymbol{R}^{\mathbf{2}}$ \\
\hline$X_{1}(\mathrm{~T})$ (linear) & 0.558 & 1 & 0.558 & 0.659 & 0.428 & 0.94 \\
$X_{1}(\mathrm{~T})$ (quadratic) & 19.038 & 1 & 19.038 & 22.492 & 0.002 & \\
$X_{2}(\mathrm{pH})$ (linear) & 62.340 & 1 & 62.340 & 73.650 & 0.000 & \\
$X_{2}(\mathrm{pH})$ (quadratic) & 137.038 & 1 & 137.038 & 161.900 & 0.000 & \\
Interaction $X_{1} X_{2}$ & 0.120 & 1 & 0.120 & 0.142 & 0.711 & \\
Error & 13.543 & 16 & 0.846 & & & \\
\hline Total & 214.527 & 21 & & & & \\
\hline
\end{tabular}

$\mathrm{SS}=$ sum square. $\mathrm{DF}=$ degrees of freedom. $\mathrm{MS}=$ mean square. $\mathrm{T}=$ temperature in ${ }^{\circ} \mathrm{C}$.

The determination coefficient $\left(R^{2}\right)$ of 0.94 indicates that $94 \%$ of the experimental data fitted the model. The polynomial model $(Y)$ representing the activity of $\beta$-glucosidase of extracts from EGS is described below:

$$
Y=11.39+0.18 x_{1}-1.29 x_{1}^{2}-1.97 x^{2}-3.48 x_{2}^{2}+0.12 x_{1} x_{2}
$$

where $x_{1}$ and $x_{2}$ are the coded variables representing the temperature and $\mathrm{pH}$, respectively, for the optimum recovery of high-activity $\beta$-glucosidase extracts from EGS.

According to the results in Table 4, extracts obtained at 30 or $35^{\circ} \mathrm{C}$ and low $\mathrm{pH}$ values of 3.6 or 4.0 (assays 10 and 3, respectively) showed lower $\beta$-glucosidase activity. In contrast, higher $\beta$-glucosidase activity was found in extracts obtained at $23^{\circ} \mathrm{C}$ and pH 5.0 (assay 8), $25^{\circ} \mathrm{C}$ and pH 6.0 (assay 2), $30^{\circ} \mathrm{C}$ and pH 6.4 (assay 11), and $37^{\circ} \mathrm{C}$ and pH 5.0 (assay 9). Finally, the response surface (Figure 1) 
shows that the highest $\beta$-glucosidase activity was obtained when the extractions were performed at the central point, i.e., at $30{ }^{\circ} \mathrm{C}$ and $\mathrm{pH} 5.0$ (assays 5, 6, and 7). Furthermore, extracts with high $\beta$-glucosidase activity could also be obtained at temperatures ranging from 27.5 to $33.5^{\circ} \mathrm{C}$ and $\mathrm{pH}$ from 4.9 to 5.5 . The conditions used as the central point were also in good agreement with the desirability parameter of the proposed model (Figure 2), thus supporting the procurement of extracts with a high $\beta$-glucosidase activity at $30^{\circ} \mathrm{C}$ and $\mathrm{pH} 5.0$.

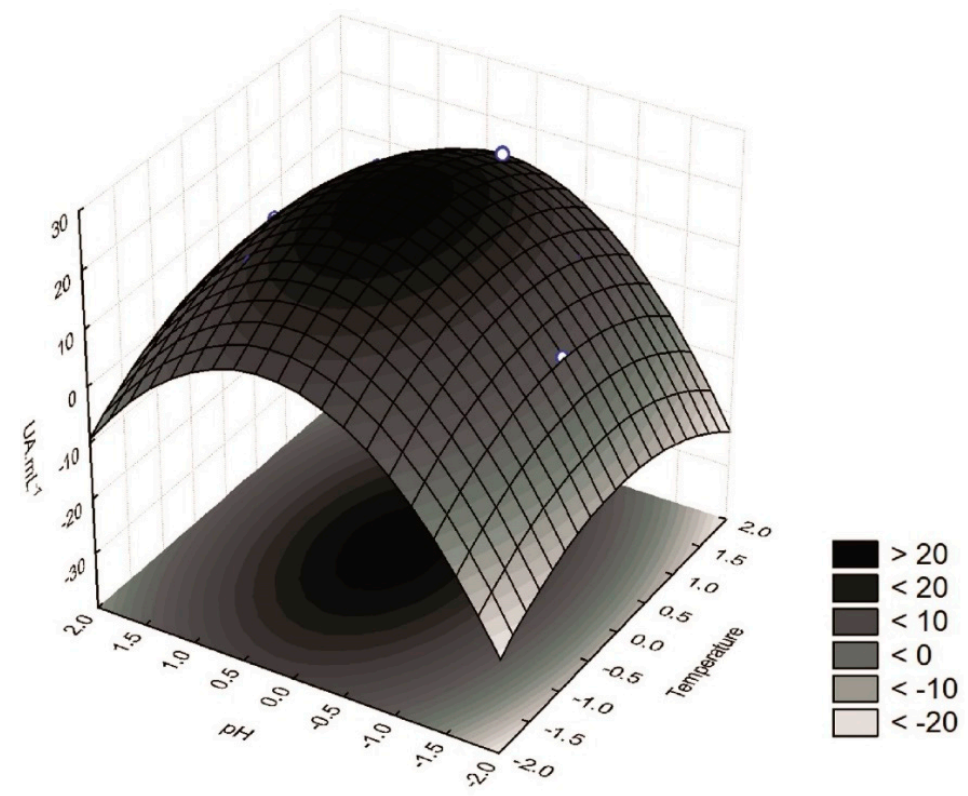

Figure 1. Surface response for the activity of $\beta$-glucosidase (UA mL ${ }^{-1}$ ) from epicotyls from germinated soybeans.



Figure 2. Profiles for predicted values and desirability for $\beta$-glucosidase activity of extracts from epicotyls from germinated soybeans. 
Table 4. Central composite design with two coded $\left(x_{1}\right.$ and $\left.x_{2}\right)$ and decoded $\left(X_{1}\right.$ and $\left.X_{2}\right)$ variables and the response function $(Y)$ for the activity of $\beta$-glucosidase from epicotyls from germinated soybeans.

\begin{tabular}{cccccc}
\hline \multirow{2}{*}{ Assays } & \multicolumn{2}{c}{ Coded Variables } & \multicolumn{2}{c}{ Decoded Variable } & \multicolumn{2}{c}{ Response Function $(\boldsymbol{Y})$} \\
\cline { 2 - 5 } & $\boldsymbol{x}_{\mathbf{1}}$ & $\boldsymbol{x}_{\mathbf{2}}$ & $\mathbf{T}\left({ }^{\circ} \mathbf{C}\right)\left(\boldsymbol{X}_{\mathbf{1}}\right)$ & $\mathbf{p H}\left(\boldsymbol{X}_{\mathbf{2}}\right)$ & $\beta$-Glucosidase Activity (UA $\left.\mathbf{~ m L}^{-\mathbf{1}}\right)$ \\
\hline 1 & -1 & -1 & 25.0 & 4.0 & 8.16 \\
2 & -1 & 1 & 25.0 & 6.0 & 17.7 \\
3 & 1 & -1 & 35.0 & 4.0 & 6.22 \\
4 & 1 & 1 & 35.0 & 6.0 & 16.7 \\
5 & 0 & 0 & 30.0 & 5.0 & 22.4 \\
6 & 0 & 0 & 30.0 & 5.0 & 23.0 \\
7 & 0 & 0 & 30.0 & 5.0 & 23.0 \\
8 & -1.41 & 0 & 23.0 & 5.0 & 16.5 \\
9 & 1.41 & 0 & 37.0 & 5.0 & 20.7 \\
10 & 0 & -1.41 & 30.0 & 3.6 & 5.76 \\
11 & 0 & 1.41 & 30.0 & 6.4 & 13.9 \\
\hline
\end{tabular}

Matsuura and Obata [26] extracted, partially purified, and characterized $\beta$-glucosidases from soybean cotyledons under different conditions including lower temperatures (between -10 and $5{ }^{\circ} \mathrm{C}$ ). Although the extraction of $\beta$-glucosidase from cotyledons has been studied by these authors, to the best of our knowledge, the procurement of extracts with high $\beta$-glucosidase activity from germinated soybean epicotyls has not been reported in the literature. Furthermore, our proposed model proved to be advantageous to establish the best conditions to obtain extracts with high enzyme activity. In addition, working at $30^{\circ} \mathrm{C}$ offers more operational advantages compared to the lower temperatures (between -10 and $5^{\circ} \mathrm{C}$ ) reported in the literature [26]. The proposed model was validated with an additional experiment under optimal conditions and the results (Figure 4) fell within the confidence interval of the estimated response, thus confirming the validity of the model.

\subsection{Optimization of the Recovery of Aglycones Using $\beta$-Glucosidase from Germinated Soybean Epicotyls}

According to variance analysis (ANOVA), the linear effect of the variable $\mathrm{X}_{4}(\mathrm{pH})$ and quadratic effects of the variables $\mathrm{X}_{3}\left({ }^{\circ} \mathrm{C}\right)$ and $\mathrm{X}_{4}(\mathrm{pH})$ were significant. However, the effects of the block, linear variable $X_{3}\left({ }^{\circ} \mathrm{C}\right)$, and the interaction of the variables $X_{3}\left({ }^{\circ} \mathrm{C}\right)$ and $X_{4}(\mathrm{pH})$ on the response $(W=\%$ aglycones) were not significant (Table 5). Therefore, nonsignificant terms were excluded from the model which did not affect the $R^{2}$. The coefficient of determination $\left(R^{2}\right)$ was 0.86 , in other words, $86 \%$ of experimental data can be explained by the model. Therefore, Equation (3) is described as follows:

$$
W=81.938+22.328 x_{4}-11.231 x_{4}^{2}-13.8562 x_{3}^{2}
$$

where $W=\%$ aglycones and $x_{3}$ and $x_{4}$ are the coded variables representing the temperature and $\mathrm{pH}$, respectively.

Table 5. Analysis of variance (ANOVA) for the conversion of conjugated isoflavones into their corresponding aglycones.

\begin{tabular}{clcllll}
\hline Variation Source & \multicolumn{1}{c}{ SS } & DF & \multicolumn{1}{c}{ MS } & F test & \multicolumn{1}{c}{$p$} & $\boldsymbol{R}^{\mathbf{2}}$ \\
\hline Block & 22.050 & 1 & 22.050 & 0.17864 & 0.683680 & 0.86 \\
$\left(X_{4}\right) \mathrm{pH}$ (Linear) & 4217.201 & 1 & 4217.201 & 34.16513 & 0.000385 & \\
$\left(\mathrm{X}_{4}\right) \mathrm{pH}$ (Quadratic) & 872.759 & 1 & 872.759 & 7.07055 & 0.028848 & \\
$\left(\mathrm{X}_{3}\right) \mathrm{T}$ (Quadratic) & 1328.402 & 1 & 1328.402 & 10.76189 & 0.011179 & \\
Error & 987.486 & 8 & 123.436 & & & \\
\hline Total & 7231.600 & 12 & & & & \\
\hline
\end{tabular}

$\mathrm{SS}=$ sum square $. \mathrm{DF}=$ degrees of freedom. $\mathrm{MS}=$ mean square. $\mathrm{T}=$ temperature in ${ }^{\circ} \mathrm{C}$. 
The aglycone content of the soybean cotyledon flour (BRS 257) devoid of $\beta$-glucosidase addition was $2.9 \%$ and, regardless of the temperature $\left(X_{3}\right)$, reached values higher than $47 \%$ (Table 6 ) with greater $\mathrm{pH}\left(\mathrm{X}_{4}\right)$ values $(0,+1$, and +1.41$)$. This suggests a greater $\mathrm{pH}$ influence on the response function ( $W=\%$ of aglycones), thus supporting the screening of the main effects.

Table 6. Central composite design with two coded $\left(x_{3}\right.$ and $\left.x_{4}\right)$ and decoded $\left(X_{3}\right.$ and $\left.X_{4}\right)$ variables and the response function $(W)$ for the conversion of conjugated isoflavones into their corresponding aglycones.

\begin{tabular}{ccccccc}
\hline \multirow{2}{*}{ Assays } & Block & \multicolumn{2}{c}{ Coded Variables } & \multicolumn{2}{c}{ Decoded Variables } & Response Function $(\boldsymbol{W})$ \\
\cline { 2 - 6 } & & $\boldsymbol{x}_{\mathbf{3}}$ & $\boldsymbol{x}_{\mathbf{4}}$ & $\mathbf{T}\left({ }^{\circ} \mathbf{C}\right)\left(\boldsymbol{X}_{\mathbf{3}}\right)$ & $\mathbf{p H}\left(\boldsymbol{X}_{\mathbf{4}}\right)$ & \% Aglycones * \\
\hline 1 & 1 & -1 & -1 & 20.0 & 4.00 & 47.5 \\
2 & 1 & +1 & -1 & 50.0 & 4.00 & 44.6 \\
3 & 1 & -1 & +1 & 20.0 & 7.00 & 68.6 \\
4 & 1 & +1 & +1 & 50.0 & 7.00 & 84.0 \\
$5(\mathrm{c})$ & 1 & 0 & 0 & 35.0 & 5.50 & 88.6 \\
$6(\mathrm{c})$ & 1 & 0 & 0 & 35.0 & 5.50 & 88.0 \\
$7(\mathrm{c})$ & 1 & 0 & 0 & 35.0 & 5.50 & 11.6 \\
8 & 2 & 0 & -1.41 & 35.0 & 3.39 & 98.7 \\
9 & 2 & 0 & +1.41 & 35.0 & 7.61 & 48.6 \\
10 & 2 & -1.41 & 0 & 13.9 & 5.50 & 87.1 \\
11 & 2 & +1.41 & 0 & 56.2 & 5.50 & 88.3 \\
$12(\mathrm{c})$ & 2 & 0 & 0 & 35.0 & 5.50 & 5.3 \\
$13(\mathrm{c})$ & 2 & 0 & 0 & 35.0 & 5.50 & \\
\hline
\end{tabular}

*\% aglycone isoflavones relative to total isoflavones extracted, determined by ultra-high-performance liquid chromatography (UHPLC). High-aglycone defatted soybean cotyledon flours were produced by treatment with $\beta$-glucosidase from germinated soybean epicotyls. " $c$ " is central point.

The response surface (Figure 3) shows a region at which more than $80 \%$ of the isoflavones recovered were in the aglycone form, i.e., a $\mathrm{pH}$ range between +0.5 and $+1.5(6.25<\mathrm{pH}<7.75)$ and a temperature between -0.5 and $+0.5(27.5<\mathrm{T}<42.5)$. Furthermore, an optimum region at which the maximum percentage of isoflavones in the aglycone form was recovered could be determined. The desirability parameter indicates two optimal points of maximum ( $W=98.7 \%$ aglycones), i.e., when $x_{3}=0\left(35^{\circ} \mathrm{C}\right)$ and $x_{4}=+1$ or $+1.41(\mathrm{pH}=7.00$ and 7.61). One of these test points coincides with assay 9 ( $Z=98.7 \%$ aglycones). These results are distinct from the optimum conditions of $\mathrm{pH}$ (between 5.2 and 6.0) and temperature $\left(50^{\circ} \mathrm{C}\right)$ for $\beta$-glucosidase activity from soybean cell tissue described by Hosel and Todenhagen [29] and by Matsuura and Obata [30] who reported optimal activity at pH 4.5 and a temperature of $45^{\circ} \mathrm{C}$ for a soybean $\beta$-glucosidase. However, the proposed models were validated for both response functions which were within the confidence interval of the model (Figure 4).

A complete conversion of glycosidic isoflavones into their aglycones has been described by other authors [31]. However, their study was conducted with $\beta$-glucosidase from microbial origin (Lactobacillus (L.) rhamnosus CRL981). Furthermore, Song and Yu [32] applied $\beta$-glucosidase from Thermotoga maritima to recombinant soybean flour and obtained an almost complete conversion of all isoflavone glycosides. Endogenous $\beta$-glucosidases represent a more secure source of $\beta$-glucosidases than microbial sources. However, endogenous $\beta$-glucosidases have been poorly explored when compared with the microbial conversion of conjugated isoflavones into their aglycone forms. As mentioned before, in the present study, the maximum aglycone isoflavones obtained was $98.7 \%$ when endogenous $\beta$-glucosidase from EGS was used under the two conditions described above, therefore providing strong evidence on the potential use of EGS as a great source of endogenous $\beta$-glucosidase. 


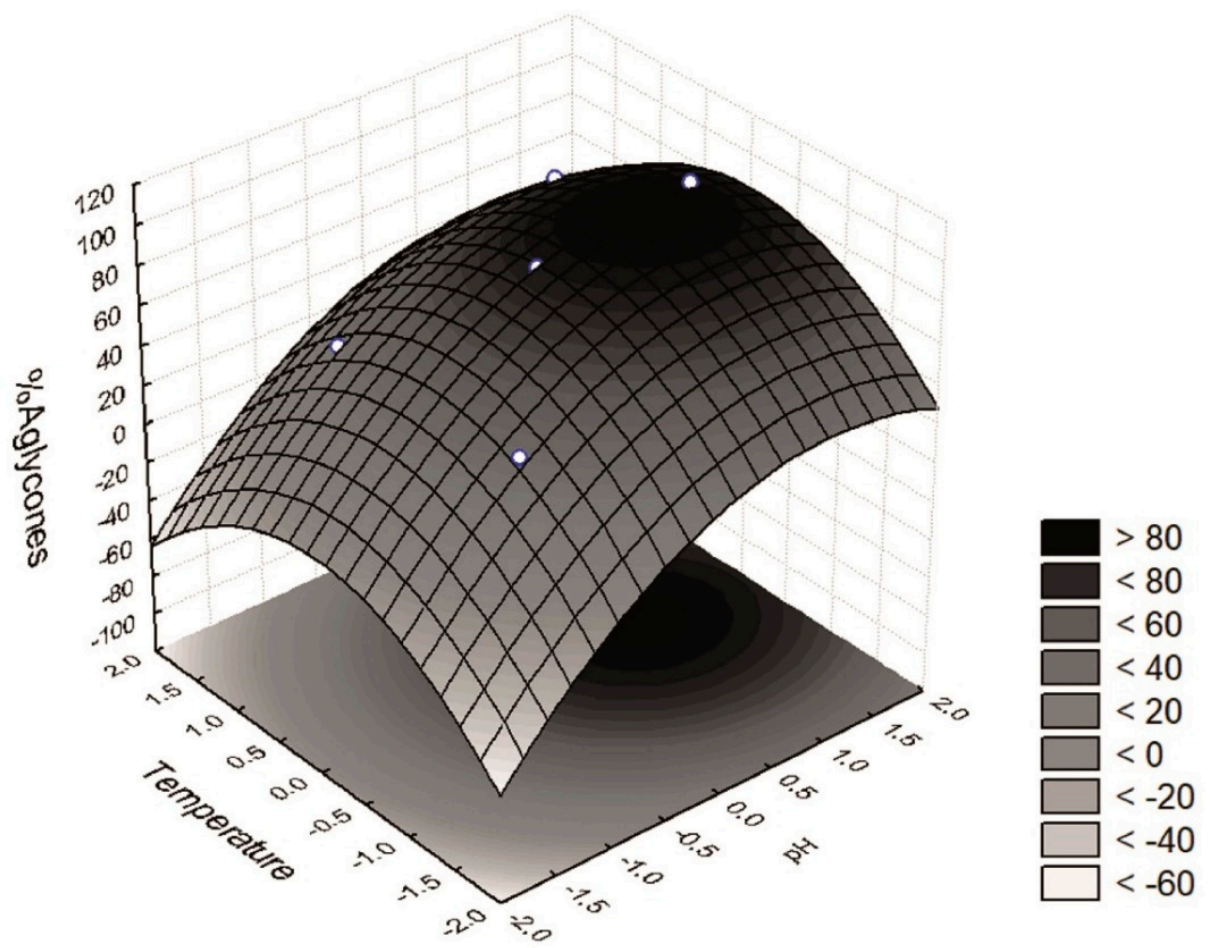

Figure 3. Surface response for the conversion of glycosidic isoflavones into their corresponding aglycones. High-aglycone defatted soybean cotyledon flours were produced by treatment with $\beta$-glucosidase from germinated soybean epicotyls.

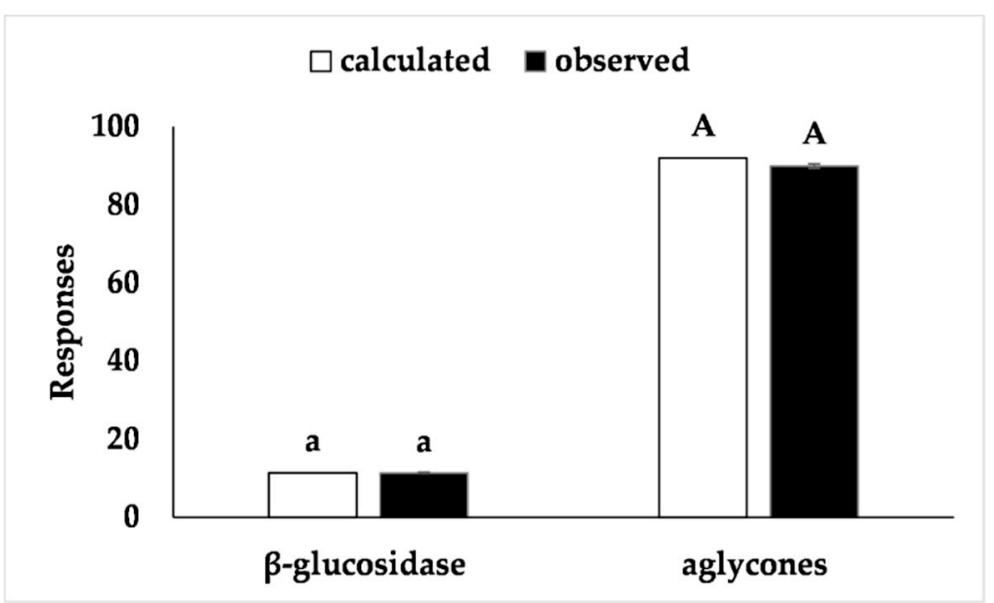

Figure 4. Validation of the models proposed for the procurement of extracts with $\beta$-glucosidase from epicotyls from germinated soybeans and high-aglycone defatted soybean cotyledon flours. Means with the same lower case ( $\beta$-glucosidase) or capital (aglycones) letters: results fall within the confidence interval of the generated model.

Several pieces of evidence have demonstrated that different plant parts may present different phenolic compounds [33-39], therefore suggesting that the expression of genes associated with the production of some enzymes may be tissue specific. Likewise, not only the absorption of the phenolics is important but also their structure/activity [40-42]. Perera et al. [40] demonstrated that epigallocatechin gallate derivatives procured via lipophilization showed enhanced antioxidant properties compared with those of epigallocatechin gallate. Likewise, Oh and Shahidi [42] reported that several lipophilized resveratrol derivatives had better hydrogen peroxide scavenging activity 
than resveratrol. In addition, Oldoni et al. [41] demonstrated that minor changes such as the position of the hydroxyl group in flavonoids may be responsible for major changes in their final effects. According to their study, the concentration of procyanidin A2 necessary to scavenge $50 \%$ of the DPPH radical was 1.7-fold higher than that of procyanidin A1. Besides the antioxidant activity, which may be related to the inhibition of low-density lipoprotein cholesterol oxidation and DNA damage $[43,44]$, phenolic compounds have been regarded as potential inhibitors of enzymes related to the absorption of carbohydrates and lipids [38,45]. In a bioactivity-guided isolation and purification study to identify $\alpha$-glucosidase inhibitors, Sun et al. [46] suggested that $\mathrm{C}_{1}-\mathrm{OH}$ of the saccharide moiety in phenolic glycosides are necessary for a potent inhibition of intestinal $\alpha$-glucosidases. According to Bustanji et al. [47], the inhibitory effect towards lipase activity was in the order of gallic acid $>$ caffeic acid $>$ chlorogenic acid $>$ rosmarinic acid. A recent study [37] also demonstrated that whereas proanthocyanidin-rich extracts showed higher antioxidant activity, the extracts containing only phenolic acids showed higher antimicrobial effects. Finally, inflammation has been linked to several health issues, including those related to oxidative stress. A myriad of phenolic compounds have been reported to act as potential anti-inflammatory and antioxidant compounds [39,48-50] and the link between inflammatory responses and several diseases is well recognized. According to Lee et al. [51], fermented soymilk with greater contents of isoflavones in the aglycone form also showed higher antioxidant properties. The importance of natural product characterization in studies related to their bioactivity has long been discussed $[52,53]$. Therefore, by understanding the best conditions to produce $\beta$-glucosidase from EGS as well as its further application in the procurement of high-aglycone defatted soybean cotyledon flours, the present study contributes to both basic and applied science related to food bioactives and health.

\section{Conclusions}

EGS was demonstrated to be of great potential as a source of endogenous $\beta$-glucosidase. Furthermore, two models were optimized, both for the extraction of $\beta$-glucosidase from EGS and for further application in defatted soybean cotyledon flour. Optimum extraction of $\beta$-glucosidase from EGS was procured at $30^{\circ} \mathrm{C}$ and $\mathrm{pH} 5.0$ whereas the maximum recovery of aglycones (98.7\%) occurred at $35^{\circ} \mathrm{C}$ and $\mathrm{pH}$ ranging from 7.0 to 7.6. The higher bioaccessibility of aglycones when compared with their conjugated counterparts has already been discussed by other authors [54,55]. Furthermore, the structure/activity has also been in the spotlight. Therefore, by reporting the best conditions to obtain a high-aglycone soybean feedstock, the present contribution may be useful for enhancing knowledge about the potential benefits of soybean products and/or processing by-products.

Author Contributions: Conceptualization, E.I.I. and L.Y.Y.; Methodology, A.C.d.C., E.I.I., L.Y.Y.; Software, L.Y.Y. and T.B.M.; Validation, L.Y.Y. and T.B.M.; Formal Analysis, L.Y.Y. and T.B.M.; Investigation, L.Y.Y. and T.B.M.; Resources, E.I.I.; Data Curation, L.Y.Y.; Writing-Original Draft Preparation, E.I.I. and L.Y.Y.; Writing-Review \& Editing, A.C.d.C., E.I.I., F.S., and L.Y.Y.; Supervision, E.I.I.; Project Administration, E.I.I.; Funding Acquisition, E.I.I.

Funding: This research was partially funded by CNPq/MCT and Fundação Araucária/PR. L. Y. Yoshiara and T. B. Madeira would like to thank CNPq for their PhD and undergraduate scholarships, respectively. F. Shahidi thanks the Natural Science and Engineering Research Council (NSERC) of Canada for partial financial support. A. C. de Camargo is thankful to Coordination of Improvement of Higher Education-Ministry of Education of Brazil-CAPES for his postdoctoral fellowship. E. I. Ida is a CNPq Research Fellow.

Acknowledgments: The authors are thankful to Embrapa Soybean (Londrina, PR, Brazil) for providing the soybeans used in this investigation.

Conflicts of Interest: The authors declare no conflict of interest.

\section{References}

1. Hsieh, M.-C.; Graham, T.L. Partial purification and characterization of a soybean $\beta$-glucosidase with high specific activity towards isoflavone conjugates. Phytochemistry 2001, 58, 995-1005. [CrossRef] 
2. Villares, A.; Rostagno, M.A.; García-Lafuente, A.; Guillamón, E.; Martínez, J.A. Content and profile of isoflavones in soy-based foods as a function of the production process. Food Bioprocess Technol. 2011, 4, 27-38. [CrossRef]

3. He, F.-J.; Chen, J.-Q. Consumption of soybean, soy foods, soy isoflavones and breast cancer incidence: Differences between Chinese women and women in western countries and possible mechanisms. Food Sci. Hum. Wellness 2013, 2, 146-161. [CrossRef]

4. Brandi, M.L. Natural and synthetic isoflavones in the prevention and treatment of chronic diseases. Calcif. Tissue Int. 1997, 61, S5-S8. [CrossRef] [PubMed]

5. Adlercreutz, H.; Mazur, W. Phyto-oestrogens and western diseases. Ann. Med. 1997, 29, 95-120. [CrossRef] [PubMed]

6. Falcão, H.G.; Handa, C.L.; Silva, M.B.R.; de Camargo, A.C.; Shahidi, F.; Kurozawa, L.E.; Ida, E.I. Soybean ultrasound pre-treatment prior to soaking affects $\beta$-glucosidase activity, isoflavone profile and soaking time. Food Chem. 2018. [CrossRef]

7. Kudou, S.; Fleury, Y.; Welti, D.; Magnolato, D.; Uchida, T.; Kitamura, K.; Okubo, K. Malonyl isoflavone glycosides in soybean seeds (Glycine max Merrill). Agric. Biol. Chem. 1991, 55, 2227-2233. [CrossRef]

8. Wang, H.J.; Murphy, P.A. Isoflavone content in commercial soybean foods. J. Agric. Food Chem. 1994, 42, 1666-1673. [CrossRef]

9. Tsukamoto, C.; Shimada, S.; Igita, K.; Kudou, S.; Kokubun, M.; Okubo, K.; Kitamura, K. Factors affecting isoflavone content in soybean seeds: Changes in isoflavones, saponins, and composition of fatty acids at different temperatures during seed development. J. Agric. Food Chem. 1995, 43, 1184-1192. [CrossRef]

10. Walsh, K.R.; Zhang, Y.C.; Vodovotz, Y.; Schwartz, S.J.; Failla, M.L. Stability and bioaccessibility of isoflavones from soy bread during in vitro digestion. J. Agric. Food Chem. 2003, 51, 4603-4609. [CrossRef] [PubMed]

11. Fukutake, M.; Takahashi, M.; Ishida, K.; Kawamura, H.; Sugimura, T.; Wakabayashi, K. Quantification of genistein and genistin in soybeans and soybean products. Food Chem. Toxicol. 1996, 34, 457-461. [CrossRef]

12. Izumi, T.; Piskula, M.K.; Osawa, S.; Obata, A.; Tobe, K.; Saito, M.; Kataoka, S.; Kubota, Y.; Kikuchi, M. Soy isoflavone aglycones are absorbed faster and in higher amounts than their glucosides in humans. J. Nutr. 2000, 130, 1695-1699. [CrossRef] [PubMed]

13. Matsuura, M.; Obata, A.; Fukushima, D. Objectionable flavor of soy milk developed during the soaking of soybeans and its control. J. Food Sci. 1989, 54, 602-605. [CrossRef]

14. Esen, A. Purification and partial characterization of maize (Zea mays L.) beta-glucosidase. Plant Physiol. 1992, 98, 174-182. [CrossRef] [PubMed]

15. Kuo, L.C.; Cheng, W.Y.; Wu, R.Y.; Huang, C.J.; Lee, K.T. Hydrolysis of black soybean isoflavone glycosides by Bacillus subtilis natto. Appl. Microbiol. Biotechnol. 2006, 73, 314-320. [CrossRef] [PubMed]

16. Chuankhayan, P.; Rimlumduan, T.; Svasti, J.; Cairns, J.R.K. Hydrolysis of soybean isoflavonoid glycosides by Dalbergia ß-glucosidases. J. Agric. Food Chem. 2007, 55, 2407-2412. [CrossRef] [PubMed]

17. Handa, C.L.; Couto, U.R.; Vicensoti, A.H.; Georgetti, S.R.; Ida, E.I. Optimisation of soy flour fermentation parameters to produce $\beta$-glucosidase for bioconversion into aglycones. Food Chem. 2014, 152, 56-65. [CrossRef] [PubMed]

18. Morant, A.V.; Jørgensen, K.; Jørgensen, C.; Paquette, S.M.; Sánchez-Pérez, R.; Møller, B.L.; Bak, S. $\beta$-Glucosidases as detonators of plant chemical defense. Phytochemistry 2008, 69, 1795-1813. [CrossRef] [PubMed]

19. Santosh, T.R.; Balasubramanian, K.K.; Lalitha, K. Enhancement of $\beta$-Glucosidase and $\beta$-Galactosidase of Trigonella foenum-graecum by exposure to the allelochemical mimosine. J. Agric. Food Chem. 1999, 47, 462-467. [CrossRef] [PubMed]

20. Ribeiro, M.L.L.; Mandarino, J.M.G.; Carrão-Panizzi, M.C.; Oliveira, M.C.N.; Campo, C.B.H.; Nepomuceno, A.L.; Ida, E.I. $\beta$-Glucosidase activity and isoflavone content in germinated soybean radicles and cotyledons. J. Food Biochem. 2006, 30, 453-465. [CrossRef]

21. Yoshiara, L.Y.; Madeira, T.B.; Ribeiro, M.L.L.; Mandarino, J.M.G.; Carrão-Panizzi, M.C.; Ida, E.I. $\beta$-Glucosidase activity of soybean (Glycine max) embryonic axis germinated in the presence or absence of light. J. Food Biochem. 2011, 36, 699-705. [CrossRef]

22. Ferreres, F.; Grosso, C.; Gil-Izquierdo, A.; Valentão, P.; Mota, A.T.; Andrade, P.B. Optimization of the recovery of high-value compounds from pitaya fruit by-products using microwave-assisted extraction. Food Chem. 2017, 230, 463-474. [CrossRef] [PubMed] 
23. He, B.; Zhang, L.-L.; Yue, X.-Y.; Liang, J.; Jiang, J.; Gao, X.-L.; Yue, P.-X. Optimization of ultrasound-assisted extraction of phenolic compounds and anthocyanins from blueberry (Vaccinium ashei) wine pomace. Food Chem. 2016, 204, 70-76. [CrossRef] [PubMed]

24. Liyana-Pathirana, C.; Shahidi, F. Optimization of extraction of phenolic compounds from wheat using response surface methodology. Food Chem. 2005, 93, 47-56. [CrossRef]

25. Carrăo-Panizzi, M.C.; Bordingnon, J.R. Activity of beta-glucosidase and levels of isoflavone glucosides in soybean cultivars affected by the environment. Pesq. Agropec. Bras. 2000, 35, 873-878. [CrossRef]

26. Matsuura, M.; Sasaki, J.; Murao, S. Studies on $\beta$-glucosidases from soybeans that hydrolyze daidzin and genistin: Isolation and characterization of an isozyme. Biosci. Biotechnol. Biochem. 1995, 59, 1623-1627. [CrossRef]

27. Yoshiara, L.Y.; Madeira, T.B.; Delaroza, F.; Da Silva, J.B.; Ida, E.I. Optimization of soy isoflavone extraction with different solvents using the simplex-centroid mixture design. Int. J. Food Sci. Nutr. 2012, 63, 978-986. [CrossRef] [PubMed]

28. Coward, L.; Smith, M.; Kirk, M.; Barnes, S. Chemical modification of isoflavones in soyfoods during cooking and processing. Am. J. Clin. Nutr. 1998, 68, 1486S-1491S. [CrossRef] [PubMed]

29. Hösel, W.; Todenhagen, R. Characterization of a $\beta$-glucosidase from Glycine Max which hydrolyses coniferin and syringin. Phytochemistry 1980, 19, 1349-1353. [CrossRef]

30. Matsuura, M.; Obata, A. $\beta$-Glucosidases from soybeans hydrolyze daidzin and genistin. J. Food Sci. 1993, 58, 144-147. [CrossRef]

31. Marazza, J.A.; Garro, M.S.; Savoy de Giori, G. Aglycone production by Lactobacillus rhamnosus CRL981 during soymilk fermentation. Food Microbiol. 2009, 26, 333-339. [CrossRef] [PubMed]

32. Xue, Y.; Song, X.; Yu, J. Overexpression of $\beta$-glucosidase from Thermotoga maritima for the production of highly purified aglycone isoflavones from soy flour. World J. Microbiol. Biotechnol. 2009, 25, 2165-2172. [CrossRef]

33. John, J.A.; Shahidi, F. Phenolic compounds and antioxidant activity of Brazil nut (Bertholletia excelsa). J. Funct. Foods 2010, 2, 196-209. [CrossRef]

34. Peng, H.; Li, W.; Li, H.; Deng, Z.; Zhang, B. Extractable and non-extractable bound phenolic compositions and their antioxidant properties in seed coat and cotyledon of black soybean (Glycinemax (L.) Merr). J. Funct. Foods 2017, 32, 296-312. [CrossRef]

35. Arruda, H.S.; Pereira, G.A.; de Morais, D.R.; Eberlin, M.N.; Pastore, G.M. Determination of free, esterified, glycosylated and insoluble-bound phenolics composition in the edible part of araticum fruit (Annona crassiflora mart.) and its by-products by HPLC-ESI-MS/MSms. Food Chem. 2018, 245, 738-749. [CrossRef] [PubMed]

36. Ambigaipalan, P.; de Camargo, A.C.; Shahidi, F. Identification of phenolic antioxidants and bioactives of pomegranate seeds following juice extraction using HPLC-DAD-ESI-MS ${ }^{n}$. Food Chem. 2017, 221, 1883-1894. [CrossRef] [PubMed]

37. De Camargo, A.C.; Regitano-d'Arce, M.A.B.; Rasera, G.B.; Canniatti-Brazaca, S.G.; do Prado-Silva, L.; Alvarenga, V.O.; Sant'Ana, A.S.; Shahidi, F. Phenolic acids and flavonoids of peanut by-products: Antioxidant capacity and antimicrobial effects. Food Chem. 2017, 237, 538-544. [CrossRef] [PubMed]

38. De Camargo, A.C.; Regitano-d'Arce, M.A.B.; Shahidi, F. Phenolic profile of peanut by-products: antioxidant potential and inhibition of alpha-glucosidase and lipase activities. J. Am. Oil Chem. Soc. 2017, 94, 959-971. [CrossRef]

39. Tremocoldi, M.A.; Rosalen, P.L.; Franchin, M.; Massarioli, A.P.; Denny, C.; Daiuto, É.R.; Paschoal, J.A.R.; Melo, P.S.; De Alencar, S.M. Exploration of avocado by-products as natural sources of bioactive compounds. PLoS ONE 2018, 13, e0192577. [CrossRef] [PubMed]

40. Perera, N.; Ambigaipalan, P.; Shahidi, F. Epigallocatechin gallate (EGCG) esters with different chain lengths fatty acids and their antioxidant activity in food and biological systems. J. Food Bioact. 2018, 1, 124-133.

41. Oldoni, T.L.C.; Melo, P.S.; Massarioli, A.P.; Moreno, I.A.M.; Bezerra, R.M.N.; Rosalen, P.L.; da Silva, G.V.J.; Nascimento, A.M.; Alencar, S.M. Bioassay-guided isolation of proanthocyanidins with antioxidant activity from peanut (Arachis hypogaea) skin by combination of chromatography techniques. Food Chem. 2016, 192, 306-312. [CrossRef] [PubMed]

42. Oh, W.Y.; Shahidi, F. Antioxidant activity of resveratrol ester derivatives in food and biological model systems. Food Chem. 2018, 261, 267-273. [CrossRef] [PubMed] 
43. Amarowicz, R.; Pegg, R.B. The potential protective effects of phenolic compounds against low-density lipoprotein oxidation. Curr. Pharm. Des. 2017, 23, 2754-2766. [CrossRef] [PubMed]

44. De Camargo, A.C.; Regitano-d'Arce, M.A.B.; Gallo, C.R.; Shahidi, F. Gamma-irradiation induced changes in microbiological status, phenolic profile and antioxidant activity of peanut skin. J. Funct. Foods 2015, 12, 129-143. [CrossRef]

45. Rahman, M.J.; de Camargo, A.C.; Shahidi, F. Phenolic and polyphenolic profiles of chia seeds and their in vitro biological activities. J. Funct. Foods 2017, 35, 622-634. [CrossRef]

46. Sun, S.; Kadouh, H.C.; Zhu, W.; Zhou, K. Bioactivity-guided isolation and purification of $\alpha$-glucosidase inhibitor, 6-O-D-glycosides, from tinta cão grape pomace. J. Funct. Foods 2016, 23, 573-579. [CrossRef]

47. Bustanji, Y.; Issa, A.; Mohammad, M.; Hudaib, M.; Tawah, K.; Alkhatib, H.; Almasri, I.; Al-Khalidi, B. Inhibition of hormone sensitive lipase and pancreatic lipase by Rosmarinus officinalis extract and selected phenolic constituents. J. Med. Plant Res. 2010, 4, 2235-2242.

48. Denny, C.; Melo, P.S.; Franchin, M.; Massarioli, A.P.; Bergamaschi, K.B.; De Alencar, S.M.; Rosalen, P.L. Guava pomace: A new source of anti-inflammatory and analgesic bioactives. BMC Complement. Altern. Med. 2013, 13, 235. [CrossRef] [PubMed]

49. Zhang, H.; Tsao, R. Dietary polyphenols, oxidative stress and antioxidant and anti-inflammatory effects. Curr. Opin. Food Sci. 2016, 8, 33-42. [CrossRef]

50. Khang, D.T.; Dung, T.N.; Elzaawely, A.A.; Xuan, T.D. Phenolic profiles and antioxidant activity of germinated legumes. Foods 2016, 5, 27. [CrossRef] [PubMed]

51. Lee, M.; Hong, G.-E.; Zhang, H.; Yang, C.-Y.; Han, K.-H.; Mandal, P.K.; Lee, C.-H. Production of the isoflavone aglycone and antioxidant activities in black soymilk using fermentation with Streptococcus thermophilus S10. Food Sci. Biotechnol. 2015, 24, 537-544. [CrossRef]

52. Gosslau, A.; Li, S.; Ho, C.T.; Chen, K.Y.; Rawson, N.E. The importance of natural product characterization in studies of their anti-inflammatory activity. Mol. Nutr. Food Res. 2011, 55, 74-82. [CrossRef] [PubMed]

53. Amarowicz, R.; Shahidi, F. Antioxidant activity of faba bean extract and fractions thereof. J. Food Bioact. 2018, 2, 112-118.

54. Larkin, T.; Price, W.E.; Astheimer, L. The key importance of soy isoflavone bioavailability to understanding health benefits. Crit. Rev. Food Sci. Nutr. 2008, 48, 538-552. [CrossRef] [PubMed]

55. Rowland, I.; Faughnan, M.; Hoey, L.; Wähälä, K.; Williamson, G.; Cassidy, A. Bioavailability of phytooestrogens. Br. J. Nutr. 2003, 89, S45-S58. [CrossRef] [PubMed] 